\title{
Sacral Myelocele
}

National Cancer Institute

\section{Source}

National Cancer Institute. Sacral Myelocele. NCI Thesaurus. Code C98900.

Herniation of spinal cord tissue and meninges through a defect in the sacral region of the vertebral column. The protrusion of the tissue is flush with the level of the skin surface. 